\title{
marketing.
}

Članci/PaPers

\section{A Challenge of Holistic Marketing in Artistic Projects}

\author{
Bekim Ćorović, Radmila Janičić
}

\begin{abstract}
A challenge of holistic marketing approach and strategies in artistic projects is based on the inclusion of internal marketing, integrated marketing, relationship marketing and socially responsible marketing. It is also based on the inclusion of classical and modern media, as well as on the opportunities to get artistic projects closer to target audiences in a modern way. Marketing in the arts is a specific field of marketing and requires a sophisticated approach, what is a real challenge. The key to success and a good way to present artistic ideas and messages to target audiences is to research their needs and wants. The goals of artistic projects are to motivate the public to think about and become a part of the social changes. Art lends support to the social changes. Thus, marketing strategies in artistic projects represent a challenge to the holistic marketing approach. In the modern environment, branding strategies are changing and adapting to modern social media. It can be seen that artistic projects are often supported by the new media communication platforms. Relationship marketing strategies are a good way to communicate with the public. Emotional branding strategies of artistic projects represent a special challenge to the holistic marketing approach. Modern museums, such as the Louvre Museum and the Tate Modern Museum, use social media to communicate with the target audience, but especially for the new exhibitions in the field of painting, photography and sculpture. The paper presented here shows a modern example of the artistic project „The Body Language“.
\end{abstract}

Key words: Holistic marketing, marketing strategies, artistic projects, branding strategies, relationship marketing strategies, innovation strategies, social media.
JEL: M31

\section{INTRODUCTION}

The subject of this paper is a theoretical and practical approach to the holistic marketing implementation in artistic projects. Holistic marketing in artistic projects is a new field of marketing research within the academic institutions and scientific marketing associations. Serbian Marketing Association adopted Marketing in Arts and Culture as a new field of research. The goal of the paper is to develop holistic marketing approach in arts and culture. The specific goal of the paper is to enlighten the holistic marketing strategies in artistic projects. The paper gives an overview of all holistic marketing elements, internal marketing, integrated marketing, socially responsible marketing and relationship marketing in artistic projects. The key hypothesis of the paper is that the holistic marketing implementation in artistic projects is a modern platform for the development of arts and culture. The good examples of the implementation of holistic marketing approach in artistic projects are presented in the paper. These examples include the example of the Tate Modern in London, the Louvre in Paris and the Museum of Cycladic Art in Athens. Taking into consideration these examples, it is proved that the implementation of holistic marketing is of paramount importance when it comes to artistic projects. The paper highlights the modern artistic project in Serbia ,The Body Language, which raises awareness about the importance of movement and dance. Here are also presented the results of two focus groups. The first focus group includes the students' opinion on using the Internet and social media in the artistic project. The second focus group provides results including the opinion of the people from Serbia about the artistic project 'The Body Language. The participants of this focus group belong to different age groups, different professions and possess different abilities. They answered on the questions about the artistic project 'The Body Language', their passion for movement and dance, the connection between music and dance, their willingness to be a part of the artistic project and how they prepare for it. 


\section{HOLISTIC MARKETING IN ARTISTIC PROJECTS}

Artistic projects have a specific period of duration, socially responsible goals and modern communication instruments so as to improve the communication with target audiences. The planning process of artistic projects can be perceived as a product. There is a great number of theoretical approaches in holistic marketing regarding the planning process of artistic projects. It is paramount to implement the relationship marketing strategies, internal marketing strategies and integrated marketing strategies. All these strategies have to be based on a socially responsible approach. When it comes to holistic marketing and the planning process of artistic projects, branding strategies are crucial.

The challenge of holistic marketing approach is to improve the planning process of artistic projects. Here, all parts of holistic marketing approach should be included - internal marketing, integrated marketing, relationship marketing and socially responsible marketing. Internal marketing strategies improve both organizational structures of artistic projects and communication with the members of the team. Furthermore, integrated marketing strategies ensure the storytelling consistency of artistic projects. Moreover, socially responsible approach represents the base for every artistic project. The artistic projects' key mes- sages are social changes and movement. Finally, relationship marketing strategies build platforms for clear and direct communication with artistic projects' target audiences. Taking into consideration all these elements, a holistic marketing approach is a base platform for the realization of artistic projects. The elements of holistic marketing approach are presented in Figure 1. (Kotler, 2017)

The implementation of holistic marketing approach in artistic projects is challenging since target audiences are sophisticated, planning and organization processes are demanding and the social responsibility is strong. (Starcevic\&Janicic, 2014)

Relationship marketing strategies and modern media offer opportunities for direct communication with target audiences. It is important to establish strong bonds with target audiences, as well as to build trust based on the sincerity and openness of artists. The key strategies in artistic projects are innovation strategies, adaptation strategies, relationship marketing strategies, socially responsible strategies and communication strategies.

Many artistic projects motivate their audience to become part of the organization and to take part in the performance of artistic projects, using volunteer work, focus group discussions, social media discussions and the interactive communication with the

\section{FIGURE 1: Elements of holistic marketing approach}

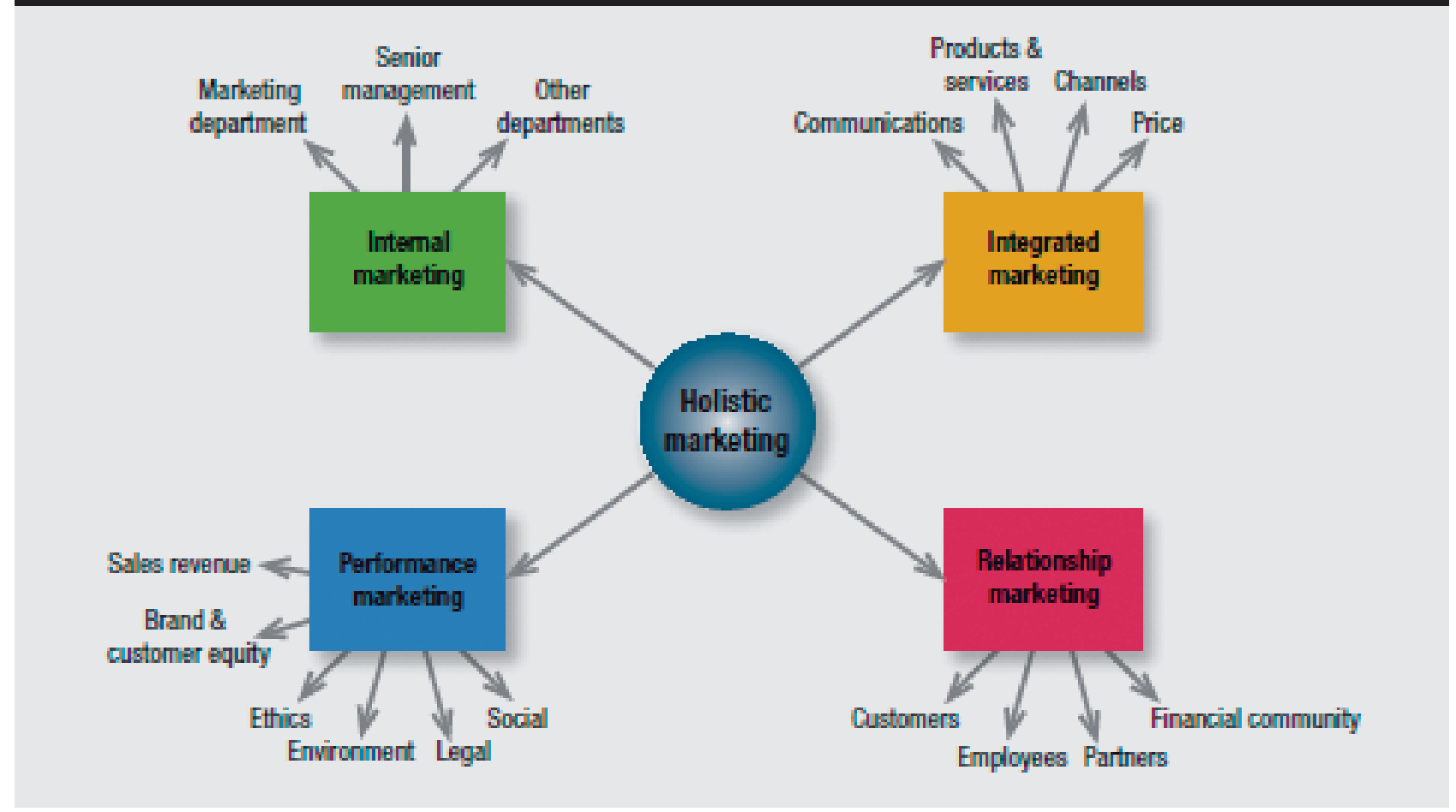


artistic project management. Through history, artistic projects have an impact on the social problems. Not only do artistic projects have an impact on the social movement, but they also raise social awareness about social problems. History facts prove that the art development raises awareness about the future movements. Art and education represent the basis for the modern society development.

Thus, a holistic marketing approach represents a base for the improvement of artistic projects. Modern society needs interactive communication through modern media. Artistic projects send messages to target audiences, but also listen to their needs and wants. The specific opportunities social media offer is the impact on awareness and attitude of the public and target audiences. (Starcevic\&Janicic, 2013)

\section{MODERN COMMUNICATION IN ARTISTIC PROJECTS}

The modern term of art is theoretically described in the second part of the 18th and the first part of the 19th century. Modern theoretical approach is established and developed by intelectual societies, in comparison to the previous aristocrates approach. When it comes to the previous approach, art was a status symbol. The new approach offers the opportunities for art to become a challenge to human souls. During the first period, art included literature, music and painting. Now, the new era includes art as a holistic project that has an impact on human souls and thoughts. Nowadays, art is not revolutionar as it was in the past. Art stimulates attitudes, souls and thoughts by storytelling and sending mesaages. (Books of modern culture, 2012)

Artistic projects are independant and artists can present their attitudes and views of the world. (Kolber, 2010)

A holistic marketing approach applies integrated marketing communication with target audiences. By applying integrated marketing communication, it becomes easier to research needs and wants of the public and social movements. It is very important that the integrated marketing communication has a consistent storytelling. Artistic projects send social impulses to the public and invite people to think about social problems, social attitudes, education, young people, future, modern civilizations, life, life stories, history, sociology. In that way, artistic projects drive people to react, express their atittude, communicate with the others and create a better world. Therefore, artistic projects are creative and drive the public to think and feel. (Pelsmacker, 2007)

The creative idea motivates the public and it is also an original approach based on imagination. Creative idea has to be clear, simple and inspiring. (Reid, 2008)

Public relations strategies are very important in the planning process of artistic projects. These strategies improve communication and connections between artistic projects and their target audiences. (Pelsmacker, 2007)

Public relations strategies develop and improve communication between the cultural institutions and their target audiences. Moreover, socially responsible approach builds a platform for artistic projects and sends messages about the purpose of artistic projects to target audiences. Relationship marketing strategies have a specific impact on artistic projects. They offer the opportunities for interactive communications with the public through both traditional communication and modern social media. Furthermore, two way communication provides the opportunities for listening to the public's wants and needs. (Kotler, 2008)

Media communication is seen as a part of artistic projects. Media culture also includes a high technology culture. This new technology gives opportunities for better communication, adding a global dimension to artistic projects. (Kelner, 2004)

The paper presented here shows a modern example of the artistic project 'The Body Language'. Here are also presented the results of two focus groups. The first focus group includes the students' opinion on using the Internet and social media in the artistic project. The second focus group provides results including the opinion of the people from Serbia about the artistic project 'The Body Language'. The participants of this focus group belong to different age groups, different professions and possess different abilities. They answered on the questions about the artistic project 'The Body Language', their passion for movement and dance, the connection between music and dance, their willingness to be a part of the artistic project and how they prepare for it.

\section{GOOD EXAMPLES OF HOLISTIC MARKETING APPROACH IN ARTISTIC PROJECTS}

One of the good examples of holistic marketing implementation in artistic projects is the Louvre $M u$ seum, one of the most important and most popular museums in the world. The Louvre Museum is located 


\section{marketing}

in Paris, near the Siene River. The museum has 35.000 presentations ranging from the prehistory period to the 20th century. The total number of the presentations is 380.000 . The Louvre Museum is the most visited museum in the world with 15.000 visits from all over the world during the work days.

The section including the description of the good examples of artistic projects focuses on the focus group with the students' opinion on artistic projects. The discussion between the students is of a major importance. Their opinions are invaluable, modern and interesting. Criteria for choosing examples was student's real experiences in these arts institutions. Focus group was lead, but, also, student's had opportunities to choose and present good examples.

The Louvre Museum has pages on all social media, including Facebook, Twitter and Instagram. The professional marketing team manages these pages so as to present cultural, historical and artistic values of the museum to the wide audience from all over the world, especially to the young people. The Louvre Museum applies a modern communication process. There are many virtual platforms that present the values of the Louvre Museum. People can discuss, ask questions and become a part of the interactive conversation about arts and culture. Today, the Louvre Museum is open for everyone in a traditional and modern way.
The participants of the first focus group say that the Louvre Museum applies modern holistic marketing strategies and that it is open to applying modern technology platforms based on the innovation and adaptation strategies. The young people think that nothing can replace the traditional visit to the museum, but the new technology gives opportunities to visit the museum virtually.

Another good example is the Tate Modern Museum in London. Not only does this museum combine modern and traditional art elements, but it also combines traditional and modern generations through artistic projects. There are no limitations in the Tate Modern Museum. The students also say that the Tate Modern is extremely innovative and inspiring. They especially like the installations, as well as the digital exhibitions. The young people also say they can go to the Tate Modern and spend a great time thinking about art, taking part in artistic projects, discussing artistic projects, listening to music, playing with art and attending the digital exhibitions from all over the world. The students highlight they are also inspired to present their own artwork and to become a part of artistic cosmopolitan world. A digital presentation of the Tate Modern is shown in Figure 2 and Figure 3.

The young people highlight that the Tate Modern is the most modern museum in the world. The museum has pages on Facebook, Twitter and Instagram. The

FiguRE 2: The Tate Modern on Social Media

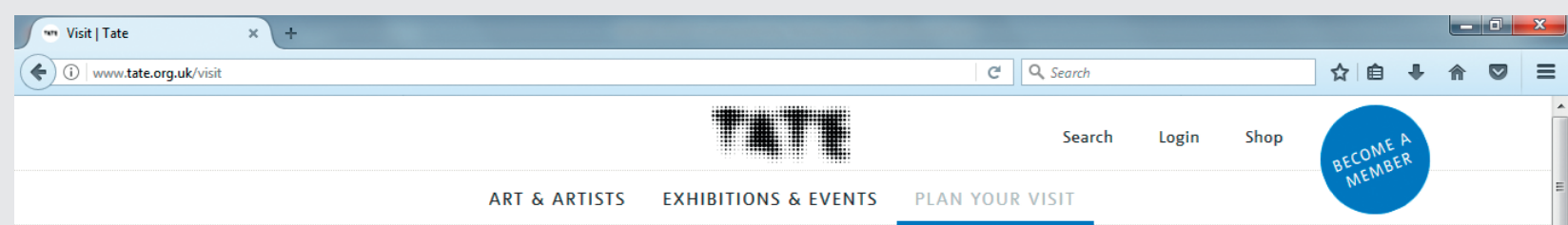

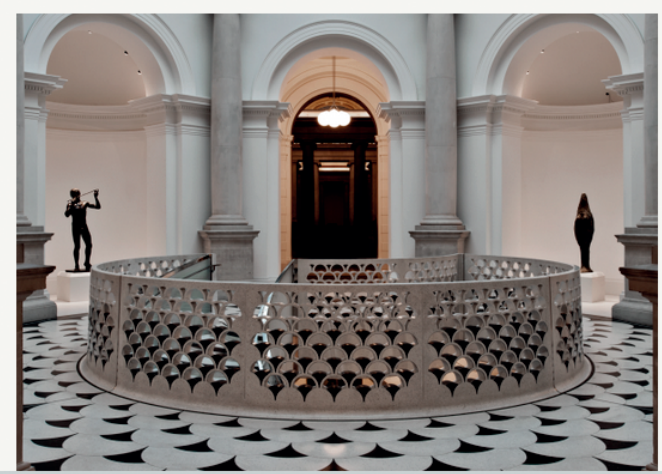

TATE + COOKIES

We use cookies to enhance your user experience. Continue with your visit by dismissing this message or find out more.
FREE ENTRY

\section{TATE BRITAIN}

The home of British art from 1500 to the present day

Extended opening hours for David Hockney: Open until 22.00 every Friday and Saturday, and further specific dates (Hockney exhibition and exhibition shop only)

Monday to Sunday 10.00-18.00

Millbank, London, SW1P 4RG 
FiguRE 3: The Tate Modern on Twitter

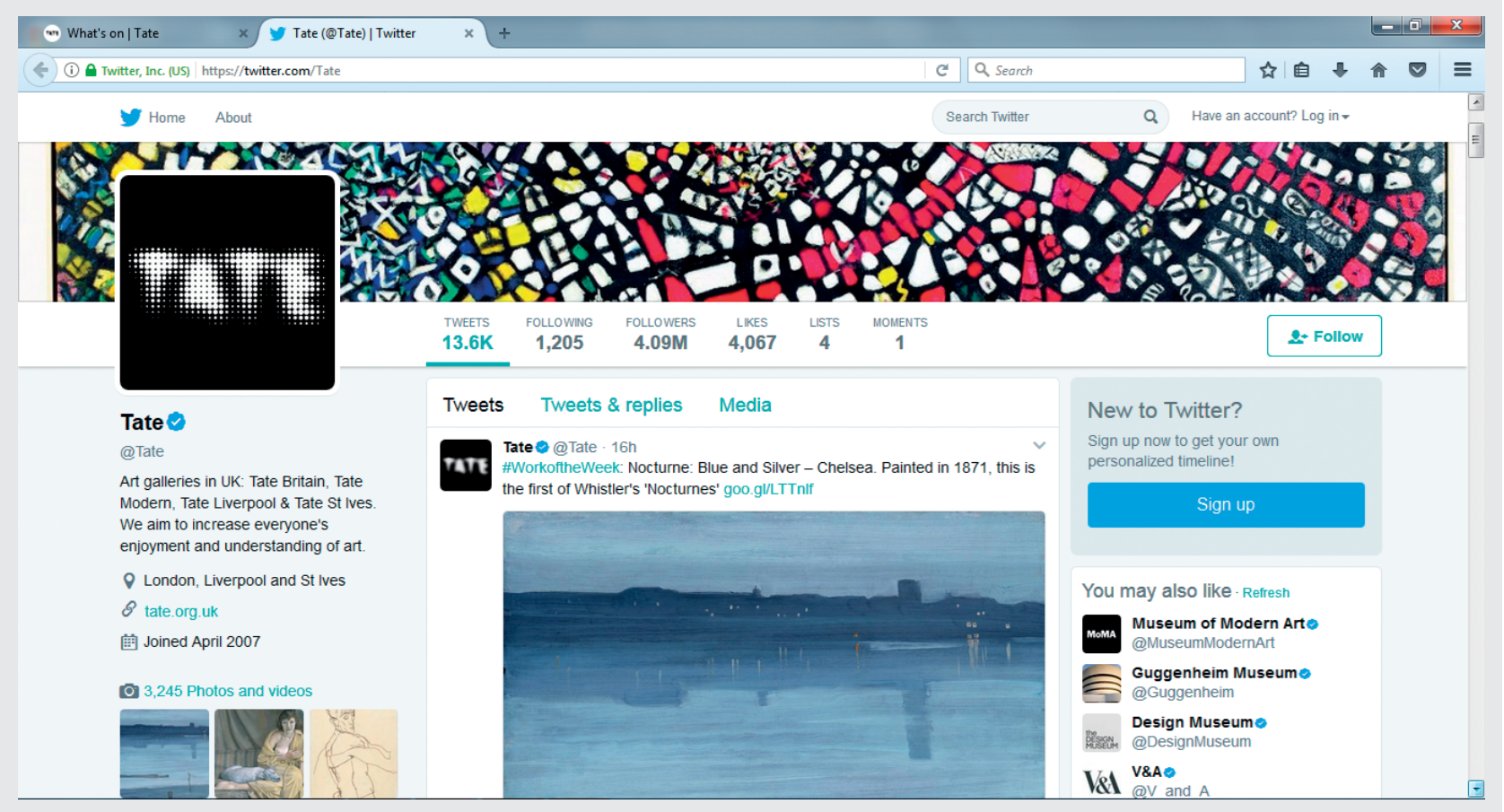

students underline that the Tate Modern offers them opportunities to take part in the interactive communication with the other young people.

Here, we can see that modern technology gives opportunities for the development. We should raise awareness about new approaches and technology, as well as motivate people to use new technology in their own way. Modern technology enables artistic projects to share opinions, new experience, new approaches, new inspirations and new ways of education.

The Museum of Cycladic Art in Athens gives opportunities to its visitors to watch digital interactive movies about sculpture reconstruction and archeological research in ancient Greece. When the visitors come to the museum, they can use interactive media players and learn about history, archeology, sociology, philosophy, culture and art. Moreover, the museum has pages on all social media platforms.

A modern way of the artistic projects development is a combination of digital media and art. The interactive digital exhibition of the life of Vincent van Gogh was the last modern exhibition in the world, which included traditional exhibition of paintings, as well as of the digital multimedia interactive movies about Vincent van Gogh's life, thoughts, dilemmas and family life. The exhibition triggered good comments and reactions on social media. This project was the digital implementation of artistic projects.

\section{THE EXAMPLE OF HOLISTIC MARKETING APPROACH IN BRAND POSITIONING OF 'THE BODY LANGUAGE'}

Holistic marketing strategies and tactics in brand positioning of 'The Body Language' in Belgrade include the integration of all holistic marketing strategies in order to develop a brand. It is important to raise awareness about beauty of dance when developing artistic project 'The Body Language'. The brand team of the project 'The Body Language' uses social marketing strategies, relationship marketing strategies, as well as internal and integrated marketing strategies. The social responsibility strategies are also a part of the project since the target audience includes all generations, pupils, students and adult people, who want to dance. Socially responsible marketing strategies increase awareness of the importance of body movement. The first target audience that includes the young people has a chance to dance professionally. The other target groups have an opportunity to dance for pleasure.

Research has been conducted so as to define what 'The Body Language' means to the target audiences. This paper provides results from the focus group including the participants' opinion on the project 'The Body Language.' The participants of the focus group are: 
Simona Sudarov, a pupil;

Gorana Nikočev, a student;

Tanja Markov, an actress, The National Theatre in Kikinda;

Branko Čipčić, a computer specialist, Bus Computers;

DanicaVujičić, a pharmaceutics specialist;

Milena Krkotić, a ballet player, the Serbian National Theatre.

The questions and answers are shown in Table 1.

TABLE 1: Focus Group Results about the project ‘The Body Language’

\section{QUESTIONS:}

Do you think that the realization of the project 'The Body Language' is a good idea?

Which associations does the name of the project 'The Body Language' evoke? What does dance mean to you? Does it mean recreation or does it have an impact on mental and physical health? Do you think that the concept of dance classes where participate dancers that belong to different age groups and have different body abilities is a good idea?

What do you think about the connection between music and dance? Is it important to you?

How do you feel when you hear music? Do you feel the need to move and dance?

What do you think, should music in the dance classes be played live or from music devices?

Does art represent an important aspect of your life and in which way?

Which media do you use? Do you think that the project has to be promoted via some traditional media, or via modern media?

What kind of a billboard or social media presentation would you like to see?

Do you think that people love to dance or would like to dance?

\section{ANSWERS:}

The questioners think that the project 'The Body Language' is a good, exciting and brilliant idea. The project will bring new movement, free dance, good feelings, good emotions, creativity and wellness.

All questioners agree that the first association is free movement, which enables them to express emotions, feelings and body language.

All questioners agree that dance is a combination of recreation and pleasure, what later leads to physical health. They also think that dancing to the music relaxes them and inspires them.

Some questioners think that dance classes where participate people that belong to different age groups are interesting, dynamic and inspiring. Mostly, questioners think that it is important to form small groups with the participants belonging to the same age groups, because young people love modern music. The conclusion is that the project has to form groups depending on the ages and music tastes. Some questioners love classical dance, while the others love modern, free dance.

Everyone thinks that there absolutely exists the connection between music and dance. All participants say that music is a part of their life. Some participants say that they cannot work without music. The young participants need music throughout the day - at home, at work, at dance classes, when on the bus or in a car.

All participants say they feel the need to move when they listen to music. Even people with some disabilities within the movement say that they would like to dance, move or attend dance classes in some way.

Half of the participants would like to listen to live music, whereas the other half would like to listen to music from music devices.

All participants say that art is an important aspect of their life. This answer is expected since all participants are part of the project 'The Body Language'.

The young participants highlight that the social media campaign should raise awareness about the importance of body movement and dance. The traditional ones underline that they would like to use the combination of classical and modern media and social networks.

The traditional participants say they would like to see a billboard in the city. They also state that they would like to see an advertisement on television or hear it on a radio. On the other hand, the young participants use social media exclusively.

All participants love to dance. The older participants love to dance, even if it was a subtle movement. This research arrives at the conclusion that movement and dance are deep human desires. 


\section{QUESTIONS:}

How many people do you know who love to dance or would like to dance? What are their excuses for not dancing?

Do you like to dance without techniques and just follow the music?

What is your profession? Do you usually sit at your work place? Are you inspired to move at your work place?

Do you like to dance at dance halls or at any other places?

There is a time plan designed for the project. What do you think, how long will it take to complete the implementation of the project 'The Body Language'?

When did you hear about modern dance? What do you think about this kind of modern free dance? What benefits does it bring for the human body and soul?

'The Body Language' is a project that starts this year in Belgrade. People that belong to different age groups, and have different professions and abilities will participate in this project. All of them love to dance and they feel that dance has a positive impact on their expressions, emotions and feelings.

The project will probably be highly positioned at the art event. The key strategies are social marketing strategies, relationship marketing and branding strategies.

'The Body Language' is a good example that shows that applying a holistic marketing approach in artistic projects offers many advantages.

\section{CONCLUSION}

Taking into consideration the theoretical analysis, comparative analysis, focus group and examples given in this paper, the conclusion is drawn that it is necessary to apply innovative marketing strategies in the field of artistic projects. It is also highlighted that the society has to provide considerable support to artistic projects. Therefore, holistic marketing approach has a great impact on social movement.

The young people, who participated in the focus group, emphasize that it is important to improve knowledge in the field of history, sociology, culture and arts, using modern media, multimedia and interactive digital movies. They also underline that it is necessary to make a connection between artistic projects and target audiences.

It can be seen that modern museums and galleries accept digital multimedia approach and holistic marketing approach. Although it is obvious that a traditional way of marketing planning of artistic projects brings many benefits and should be kept as a strategy, it should be improved by applying modern digital multimedia approach.

The paper shows which benefits holistic marketing approach brings to the project 'The Body Language'. The strategies of internal marketing, integrated marketing, socially responsible marketing, social marketing and relationship marketing offer many advantages to the project. Thus, 'The Body Language' is one of the best artistic projects in Serbia.

\section{Literature}

1. Belch, G., Belch, M. (2012). Advertising and Promotion-An Integrated Marketing Communications Perspective. New York: McGraw-Hill.
2. Blakeman, R. (2006). Integrated Marketing Communication. Toronto: McMillan.

3. David, P. (2005). Integrated Marketing Communication. Toronto: Elsevier Inc. 
4. Denegri, J. (2012). Modernizam - avangarda. Beograd: Službeni glasnik

5. Denegri, J. (2016). Posleratni modernizam neoavangarde - postmodernizam. Beograd: Službeni glasnik.

6. Filipović, V., Kostić Stanković, M. (2011). Odnosi s javnošću. Beograd: FON.

7. Filipović, V., Kostić Stanković, M. (2011). Marketing menadžment. Beograd: FON.

8. Larry, P. (2008). Strategic Integrated Marketing Communication. Toronto: Elsevier Inc.

9. Leksikon savremene kulture. (2012). Teme i teorije, oblici i institucije od 1945. do danas.

10. Kennet, C. (2008). Integrated Advertising, Promotion and Marketing Communication. New York: Prentice Hall

11. Kelner, D. (2004). Medijska kultura. Beograd: Clio.

12. Kevin, R. (2004). The Future Beyond Brands - Love marks. New York: Power House Books.

13. Kolber, F.. (2010). Marketing u kulturi i umetnosti. Beograd: Clio.

14. Kotler, Ph., Keller, L. (2008). Marketing management. $12^{\text {th }}$ Edition. London: Prentice Hall.

15. Kotler, Ph., Keller, L. (2016). Marketing management. $15^{\text {th }}$ Edition. London: Prentice Hall.
16. Malpas, S.. (2005). The Postmodern. London: Rotledge.

17. Pelsmacker, P., Geuens, M., Bergh, V. (2007). Marketing Communications. London: Prentice Hall.

18. Pickett, M. (2013). An Analysis of Narrative and Voice in Creative Nonfiction. Toronto: Journal of Arts and Humanities. Vol.2. No.7.

19. Reid, N., King, W., DeLorme, E. (2008). Top Level Agency Creatives Look at Advertising Creativity Then and Now. New York: Journal of Advertising.

20. Starčević, M., Janičić, R. (2014). Sponsorship in Culture. Belgrade: Intercultural Journal, No.8. Pp.136147. ISSN 2217-4893.

21. Starčević, M., Janičić, R. (2013). Activites of Public Relations in Servantes Institute. Belgrade: Readers, EBSCO Publishing. No.36. Pp.21-29.

22. Stojanović, S. (2012). Kulturna industrija. Beograd: Časopis Kultura - časopis za teoriju i sociologiju kulture i kutlurnu politiku. Vol.36. Beograd: Zavod za proučavanje kulturnog razvitka Republike Srbije.

23. Terence, S. (2008). Advertising Promotion and Other Aspects of Integrated Marketing Communications. New York: Prentice Hall, New York.

24. Tišma, A. (2004). Elektronska umetnost i Internet. Beograd: Časopis Signal.

\section{Apstrakt:}

\section{Izazovi holističkog marketinga u umetničkim projektima}

\section{Bekim Ćorović, Radmila Janičić}

Izazovi holističkog marketing pristupa i strategija u umetničkim projektima, zasnovani su na uključenosti internog marketinga, integrisanog marketinga, relacionog marketinga i društveno odgovornog marketinga. Holistički marketing pristup u umetničkim projektima zasnovan je na inkluziji klasičnih i modernih medija, kao i na mogućnostima da se umetnički projekti približe ciljnim grupama, na moderan način. Marketing u umetnosti je specifično polje marketinga i zahteva sofisticiran pristup, što predstavlja izazov. Ključ uspeha i dobar način predstavljanja umetničkih ideja i poruka ciljnim javnostima je spoznaja i istraživanje njihovih potreba $\mathrm{i}$ želja. Cilj umetničkih projekata je da motiviše publiku na razmišljanje o društvenim problemima, kao i da ih inspiriše da aktivno učestvuju u društvenim promenama i razvoju društva u celini. Umetnost je uvek bila pokretač društvenih promena. Stoga, marketing strate- gije u umetničkim projektima predstavljaju izazov za holistički marketing pristup. U modernom okruženju, strategije brendiranja se adaptiraju i menjaju, u skladu sa modernim, društvenim medijima. Umetnički projekti su podržani na novim, modernim, komunikacionim platformama. Strategije relacionog marketinga su dobar način da se komunicira sa publikom. Strategije emocionalnog brendiranja umetničkih projekata predstavljaju poseban izazov za holistički marketing pristup. Moderni muzeji, kao što su Louvre muzej i Tate Modern muzej, koriste društvene mreže za komunikaciju sa ciljnim javnostima, sa posebnim akcentom na novim izložbama u oblasti slikarstva, fotografije i skulpture. Rad predstavlja moderni primer umetničkog projekta, pod nazivom „Govor tela“. Ključne reči: Holistički marketing, marketing strategije, umetnički projekti, strategije brendiranja, strategije relacionog marketinga, inovacione strategije, društvene mreže.

\section{Kontakt:}

